ROBERT A. SUCHARSKI

Wydziat „Artes Liberales”

Uniwersytetu Warszawskiego

\title{
JESZCZE RAZ W KWESTII IMIENIA PIERWSZEGO HISTORYCZNEGO WŁADCY POLSKI*
}

Truizmem byłoby stwierdzenie, że Kronika polska (łac. Cronicae et gesta ducum sive principum Polonorum) należy do podstawowego korpusu źródeł dotyczących Mieszka, pierwszego historycznego, chrześcijańskiego władcy Polski. Nieznanego nam jej twórcę przyjęło się określać mianem Galla Anonima (viz. Anonima tzw. Galla).

Jacek Hertel, opierając się na opinii Henryka Łowmiańskiego, dzieli informacje na temat początków dynastii piastowskiej podawane w tejże Kronice na dwie kategorie ${ }^{1}$. Pierwszą z nich stanowią te opowieści, w przypadku których nie sposób zastosować żadnego z kryteriów oceny autentyczności, a w dodatku można w nich odnaleźć powszechnie znane wątki - mamy tutaj do czynienia zapewne ze stricte literacką topiką. Drugi typ opowieści stanowią natomiast te opierające się na źródłach, w prawdziwość których Gall Anonim nie miał powodu wątpić.

Historia o Popielu, Piaście i Rzepce oraz ich synu Siemowicie mieści się doskonale w pierwszej z dwu kategorii, narrację zaś o trzech książętach: Siemowicie, Lestku i Siemomyśle przekazała, by użyć własnego sformułowania kronikarza, „fidelis recordatio” („wierna pamięć” - tłum. Roman Grodecki). Nie wiemy dokładnie, co to znaczy; chociaż samo sformułowanie wskazywałoby raczej na ustną tradycję, to nie sposób jednak

\footnotetext{
* Chciałbym serdecznie podziękować Jerzemu Axerowi, Hieronimowi Grali oraz Henrykowi Samsonowiczowi za wskazówki metodologiczne i uzupełnienia bibliograficzne.

Pierwsza wersja artykułu została przedstawiona 25 maja 2012 r. w Poznaniu, podczas debaty naukowej pt. „Imię Mieszka I”, organizowanej przez Muzeum Archeologiczne w Poznaniu i Instytut Archeologii Uniwersytetu Kardynała Stefana Wyszyńskiego w Warszawie.

${ }^{1} \mathrm{~J}$. Hertel, Imiennictwo dynastii piastowskiej we wcześniejszym średniowieczu, Warszawa-Poznań-Toruń 1980, s. 28-30.
} 
wykluczyć, że łacińską frazę należy rozumieć szerzej i że mowa tutaj na przykład o przechowywanym w piastowskim skarbcu książęcym wykazie genealogicznym².

Dla naszych rozważań niezwykle istotny jest fakt, że opowieść o Mieszku, a konkretnie o jego dzieciństwie, następuje tuż po narracji poświęconej jego antenatom. Oznacza to zapewne, że Gall Anonim umieszcza także tę historię wśród przekazanych przez „wierną pamięć”, tym bardziej że jest ona przecież także bliższa mu chronologicznie. Nie wiemy dokładnie, kiedy kronikarz tworzył swoje dzieło, wiele wskazuje natomiast, że odbywało się to mniej więcej w latach 1112-11163. Od śmierci Mieszka minęło zatem około stu dwudziestu lat. Czy ustna tradycja, w sytuacji niezbyt rozwiniętego jeszcze piśmiennictwa, potrafi przechować informacje przez taki czas, nie zniekształcając ich zanadto? Nie mamy całkowitej pewności, by na tak postawione pytanie odpowiedzieć twierdząco, wiadomo jednak, że znajdzie się sporo przykładów, które w sposób niepodlegający dyskusji są w stanie to potwierdzić (starożytność klasyczna ilustruje to doskonale wieloma egzemplifikacjami). Ponadto, na co zwraca uwagę Marian Plezia, Gall Anonim nie pozwala sobie na świadome mijanie się z prawdą, choć „nieraz woli ją przemilczeć" ${ }^{4}$. Wiele zatem wskazuje, że informacje przekazane przez naszego kronikarza można uznać za wiarygodne. O pierwszym więc historycznym władcy Polski dowiadujemy się przede wszystkim, że przez pierwsze siedem lat życia był ślepy, że odzyskał wzrok podczas postrzyżyn, że odrzuciwszy pogańskie obyczaje, stał się chrześcijaninem i ożenił się z Dobrawą, która skłoniła go wcześniej do przyjęcia chrztu, że w końcu spłodził z Dobrawą Bolesława.

Informacja o jego ślepocie jest poprzedzona tekstem stanowiącym dopowiedzenie do imienia władcy w bierniku „Meschonem”: „Hic autem Semimizl magnum et memorandum Meschonem progenuit, qui primus nomine vocatus alio, septem annis a nativitate caecus fuit"5.

W transmisji rękopiśmiennej tekst uległ zepsuciu. Spośród trzech manuskryptów tylko pochodzący z XV w. „Rękopis Heilsberski” (H) daje lekcję: „qui primus nomine vocatus illo”, wykorzystaną w tłumaczeniu przez R. Grodeckiego: „który pierwszy nosił to imię”. Dwa pozostałe manuskryp-

\footnotetext{
${ }^{2}$ J. Hertel, op. cit., s. 29.

${ }^{3}$ Anonim tzw. Gall, Kronika polska, przełożył R. Grodecki, oprac. M. Plezia, Wrocław 1982 (wyd. 5), s. XII.

${ }^{4}$ Ibidem, s. XLV-XLVIII.

${ }^{5}$ Galla kronika, MPH, t. 1, wyd. A. Bielowski, Lwów 1864 (dalej: MPH, t. 1), s. 398. Tekst w Galli Anonymi Cronica et Gesta ducum sive principum Polonorum, wyd. K. Maleczyński, Kraków 1952, MPH n.s., t. 2 (dalej: MPH n.s., t. 2), s. 13: „Hic autem Semimizl magnum et memorandum Meschonem progenuit, qui prius nomine vocatus alio VII annis a nativitate cecus fuit".
} 
ty: uchodzący za najlepszy i jednocześnie najstarszy, pochodzący bowiem z XIV w., „Rękopis Zamojskich” (Z) oraz piętnastowieczny „Rękopis Sędziwoja” (S) poświadczają ten tekst w lekcji, użytej w wydaniu: „qui primus nomine vocatus alio". M. Plezia uznaje, że odczytywanie (za rękopisami Z i S) „alio” - „innym” zamiast „illo” - „tym” po prostu „nie daje sensu”. Niewątpliwie jest to lekcja trudna - w przekładzie na polski cały przywoływany tutaj passus winien brzmieć „ten zaś Siemomysł spłodził wielkiego i godnego pamięci Mieszka, który pierwszy nazwany innym imieniem przez siedem lat od urodzenia był ślepy". Wydaje się jednak, że tak rozumianego tekstu można bronić i ma on wszelkie przewagi właściwe lectio difficilior. Wspominając wcześniej o „wiernej pamięci”, pisze Gall Anonim o błędach pogaństwa („error et ydolatria”), charakteryzujących tych, których zapomniano: „Sed istorum gesta quorum memoriam oblivio vetustatis abolevit, et quos error et ydolatria defoedavit, memorare negligamus, et ad ea recitanda, quae fidelis recordatio meminit, istos succincte nominando transeamus"7.

Jako czytelnik Wulgaty ${ }^{8}$ kronikarz może wzorować się na rozdziale 65 z Księgi Izajasza; opisuje w nim prorok przerażający los oddających się bałwochwalstwu, przeciwstawiony szczęściu wiernych Bogu. Werset 15 tego rozdziału dotyczy konkretnie imion bałwochwalców i imion sług Bożych:

Et dimittetis nomen vestrum in iuramentum electis meis;

Et interficiet te Dominus Deus,

Et servos suos vocabit nomine alio ${ }^{9}$ [wyróżnienie: R.A.S.].

\footnotetext{
${ }^{6}$ Anonim tzw. Gall, op. cit., s. 15, p. 1. Por. również J. Strzelczyk, Mieszko Pierwszy, Poznań 1999 (wyd. 2), s. 52-53.

${ }^{7}$ Tekst łaciński za: MPH, t. 1, s. 397. Tekst w przekładzie R. Grodeckiego (Anonim tzw. Gall, op. cit., s. 14): „Lecz dajmy pokój rozpamiętywaniu dziejów ludzi, których wspomnienie zaginęło w niepamięci wieków i których skaziły błędy bałwochwalstwa, a wspomniawszy ich tylko pokrótce, przejdźmy do głoszenia tych spraw, które utrwaliła wierna pamięć".

W dwudziestowiecznym wydaniu Pomników Dziejowych Polski (MPH n.s., t. 2, s. 12) przywoływany tutaj łaciński passus brzmi identycznie (różnice polegają jedynie na pisowni „dyftongów”): „Sed istorum gesta, quorum memoriam oblivio vetustatis abolevit et quos error et ydolatria defedavit, memorare negligamus et ad ea recitanda, que fidelis recordatio meminit, istos succinte nominando transeamus".

${ }^{8}$ Anonim tzw. Gall, op. cit., s. LXI.

9 „Y zostáwićie imię swé ná przyśięgę wybránym moim: y zabiie ćię PAN Bóg, á sługi swé názowie inszem imieniem" - cytowany przekład z tzw. Biblii Wujka (Biblia to iest Księgi Starego y Nowego Testamentu, według Łacinskiego przekłádu stárègo, w kośćiele powszechnym przyiętègo, ná Polski ięzyk z nowu z pilnośćia przełożonè [- -] przez D. Iakuba Wuyka z Wągrowca, Theologa Societatis Iesu, Kraków 1599, s. 806) jest oparty na łacińskim tekście Wulgaty, w odróżnieniu od współczesnych translacji, mających swoje źródło w oryginalnych tekstach: hebrajskim, aramejskim i greckim.
} 
Przywoływany w tym miejscu cytat z Wulgaty pochodzi z dwudziestowiecznego wydania ${ }^{10}$. Już w średniowieczu istniały różne wersje tej fundamentalnej dla Kościoła Zachodu księgi, zanim Jan Gutenberg w połowie XV w. wydał redakcję Alkuina, a szesnastowieczni humaniści (Robert Estienne) i papieże (przede wszystkim Sykstus V i Klemens VIII) opracowali tekst, który obowiązywał w Kościele rzymskokatolickim aż do trzeciej ćwierci XX w., czyli do publikacji tzw. Neowulgaty w roku 1979. Interesujący nas fragment nie ulegał jednak fundamentalnym zmianom - można stwierdzić, że zachowane egzemplarze Biblii, pochodzące z XII czy XIII w., przekazują tekst Pisma św. bliski dwudziestowiecznym edycjom; czasem zdarzy się jednak przestawienie kolejności słów. I tak np. najsłynniejszy bodaj, a na pewno największy zachowany średniowieczny rękopis, „Codex Gigas” (późniejszy od tekstu Galla o mniej więcej sto lat), podaje następującą lekcję: „et dimittetis nomen vestrum in iuramentum electis meis, et interficiet te dominus, Et servos suos vocabit alio nomine"11.

Podobieństwo obrazu, ale również zgodność i odpowiedniość użytego słownictwa oraz frazeologii są uderzające i doprawdy trudno założyć, że przypadkowe ${ }^{12}$. Takie przypuszczenie pozwoli także zachować tekst łaciński z lekcją „qui primus nomine vocatus alio” bez konieczności poprawki „primus” “pierwszy' na „prius” ‘wcześniej' (wbrew opinii M.Plezi ${ }^{13}$ ); w wydaniu należałoby wówczas tylko nieco zmienić interpunkcję i na przykład wprowadzić przecinek po „qui”: „Hic autem Semimizl magnum et memorandum Meschonem progenuit, qui, primus nomine vocatus alio, septem anni a nativitate caecus fuit”. „Ten zaś Siemomysł spłodził wielkiego i godnego pamięci Mieszka, który, pierwszy nazwany innym im i e n i e m, przez siedem lat od urodzenia był ślepy".

Otrzymamy wtedy tekst bardzo dobitnie podkreślający nazwanie polańskiego księcia „innym imieniem”, czyli przyjęcie przezeń chrztu; Mieszko, jako pierwszy ochrzczony Piastowic, bez wątpienia mieści się w gronie Izajaszowych „sług Boga”, a dowodzi tego właśnie jego inne imię. To też uzasadnia w oczach kronikarza-mnicha, czy szerzej chrześcijanina, że informacja o chrzcie pojawia się w toku wypowiedzi wcześniej niż wiadomość o ślepocie. Łaciński tekst nijak jednak nie sugeruje, że jego inne imię ma być wcześniejsze chronologicznie, możemy zatem uznać, że jest nim to przyjęte

10 Biblia Sacra iuxta Vulgatam Clementinam, wyd. A. Colunga, L. Torrado, Matriti 1946, Biblioteca de Autores Cristianos, s. 967.

${ }^{11}$ Pełny tekst kodeksu (fotografie w wysokiej rozdzielczości) jest dostępny na stronach szwedzkiej Biblioteki Narodowej w Sztokholmie (〈http://www.kb.se/codex-gigas〉, dostęp: 31 III 2012).

${ }_{12}$ Por. również Iz 62, 3.

${ }^{13}$ Anonim tzw. Gall, op. cit., s. 15, p. 1. 
na chrzcie, a tu z kolei naturalnym kandydatem byłoby to właśnie, które kryje się w „Dagome iudex”. Jak dowodzi J. Hertel, analizując słynny regest i zbijając bądź przyjmując opinie poprzedników, najprościej jest uznać Dagome za „skrót dwóch imion naszego władcy: chrzestnego Dagobert i słowiańskiego Mieszko (Dago - Me)"14.

Rozumiany w ten sposób tekst znajduje poparcie także w innym Gallowym akapicie, w którym raz jeszcze podkreśla się fakt, że to Mieszko jako pierwszy z Polaków - został ochrzczony: „Primus ergo Polonorum dux Mescho per fidelem uxorem ad baptismi gratiam pervenit" 15 .

Takie odczytanie zwraca również uwagę na niebezpośredni co prawda, ale zauważalny związek zachodzący między Mieszkiem, czy też jego imieniem, a jego ślepotą. Nie ulega wątpliwości, że tę opowieść wykorzystał kronikarz alegorycznie, sam zresztą o tym pisze, gdy przedstawia Mieszkowe postrzyżyny. Wiadomo również, że podobne historie opowiada się o innych władcach (np. Jan Długosz piszący o Włodzimierzu Wielkim) należy ona zatem do określonej literackiej topiki. Nie można jednak odrzucić możliwości, że kryje się w niej ziarno prawdy, przekazywanej w rodzie piastowskim z pokolenia na pokolenie.

Informację o dziecięcej ślepocie Mieszka przejął także Mistrz Wincenty zwany Kadłubkiem ${ }^{16} \mathrm{i}$ opierający się na nim późniejsi dziejopisarze.

W nauce nowożytnej prób wyjaśnienia znaczenia imienia „Mieszko" podejmowano już wiele - zrekapitulowanie ich wszystkich wymagałoby osobnego studium, zwłaszcza gdy w weźmie się pod uwagę także te próby, które usiłują wyjaśnić „Dagome”. W odniesieniu do „Mieszka” doszukiwano się przede wszystkim zdrobnienia od imienia „Mieczysław”, „Mścisław”, od spieszczonej formy 'niedźwiedzia', tj. od 'misia'; próbowano wyjaśniać to imię jako przekształconą formę „Michała”, a nawet przez dźwiękowe podobieństwo do 'myszy' szukano źródeł imienia w Mezji17. Andrzej Bańkowski zwrócił uwagę na prasłowiański rdzeń czasownikowy: *meig $g^{(w) h}$ - 'mrugać, migać, drgać' ${ }^{18}$; na jego bazie rekonstruuje się dla prasłowiańskiego

${ }^{14}$ J. Hertel, op. cit., s. 85-95.

15 Tekst łaciński za: MPH, t. 1, s. 399. Tekst w przekładzie R. Grodeckiego: „Pierwszy więc książę polski Mieszko dostąpił łaski chrztu za sprawą wiernej żony”, tłum. R. Grodecki (Anonim tzw. Gall, op. cit., s. 17). Tekst łaciński w wersji MPH n.s., t. 2, s. 16: „Primus igitur Polonorum dux Mescho per fidelem uxorem ad baptismi graciam pervenit".

${ }^{16}$ Mistrza Wincentego kronika polska, MPH, t. 2, wyd. A. Bielowski, Lwów 1872, s. 276; Mistrza Wincentego zwanego Kadłubkiem Kronika polska, wyd. M. Plezia, Kraków 1994, MPH n.s., t. 11 (dalej: MPH n.s., t. 11), s. 38.

${ }^{17}$ O historii badań patrz przede wszystkim: G. Labuda, Mieszko I, Wrocław 2009, s. 36-43.

${ }^{18}$ Lexikon der indogermanischen Verben. Die Wurzeln und ihre Primärstammbildungen, red. H. Rix i in., Wiesbaden 2001, s. 427. 
formy czasownikowe z następującymi bezokolicznikami: *mbžati, ${ }^{*}$ mižati viz. *mbžiti, ale także *mьžěti 'przymykać oczy, przysypiać, drzemać'19. W polszczyźnie czasownik ten występował (występuje?) w formie mżeće lub obocznie mżyć albo mżeć (tę ostatnią formę już „Słownik warszawski” uznaje za mało używaną) ${ }^{21}$. Badacz z tego właśnie rdzenia wywodzi imię pierwszego historycznego władcy Polan: „Od mbžěti ‘mieć oczy zamknięte' (bo też chore) pochodzi też stp. nazwa osobowa Mieżka (†mıž-ıka, por. rus.-cs. Mežbka ${ }^{22}$ ), o księciu polskim Mieszku Starym, imię ojca Bolesława Chrobrego [--], zlatynizowane na Mesco -onis, skąd polskie podręcznikowe Mieszko"23.

Poparcia dla takiej hipotezy szuka więc badacz w źródłach ruskich. Bezcenny dla badań nad historią Rusi Kijowskiej i Halicko-Wołyńskiej, ale także nad relacjami polsko-ruskimi w XII w. Latopis kijowski zachował się w kilku manuskryptach, z których najważniejszym jest bez wątpienia Kodeks hipacki (ipatjewski) ${ }^{24}$. Pochodzi on „z początku XV w. (ścisłej daty nie znamy), był sporządzony prawdopodobnie w Pskowie, ale stanowił kopię nie zachowanego zwodu południowo-ruskiego z końca XIII w."25. Stanowiący część rękopisu Latopis kijowski został spisany w końcu XII w. i obejmuje lata $1118-1198^{26}$. Aż dziesięciokrotnie na kartach rękopisu pojawia się książę Mieszko Stary, wuj księcia halickiego Romana Mścisławi$\mathrm{cza}^{27}$. Imię polskiego władcy jest poświadczone w kilku różnych formach przypadkowych: mianowniku - Межька, dopetniaczu - Межьскъ1, celowniku - Мьжьць, bierniku - Межькоу oraz Мъжекоу, narzędniku w złożeniu -

${ }^{19}$ Por. R. Derksen, Etymological Dictionary of the Slavic Inherited Lexicon, Leiden-Boston 2008, Leiden Indo-European Etymological Dictionary Series, red. A. Lubotsky, vol. 4, s. 344, oraz Этимологический словарь славянских языков. Праславянский лексический фонд, red. О.Н. Трубачев (1974-2002), А. Ф. Журавлев (2002-), Москва 1974-, vol. 19, s. 62-63 i vol. 21, s. 179, 181-182.

${ }^{20}$ Słownik języka polskiego przez M. Samuela Bogumiła Linde, Lwów 1854-1860, t. 2, s. 194.

${ }^{21}$ Słownik języka polskiego, t. 1-8, red. J. Karłowicz, A. A. Kryński, W. Niedźwiedzki, Warszawa 1900-1927, t. 2, s. 1089.

${ }^{22}$ W druku Mıžbka, co jest zapewne błędem literowym.

${ }^{23}$ A. Bańkowski, Etymologiczny słownik języka polskiego, t. 2, Warszawa 2000, s. 235 236. Por. również: P. Urbańczyk, Mieszko Pierwszy Tajemniczy, Toruń 2012, s. 170.

${ }^{24}$ A. Poppe, Latopis ipatjewski, SSS, t. 3, red. W. Kowalenko i in., Wrocław 1967-1968, s. 20-21. Na temat innych manuskryptów zawierających różne wersje Latopisu kijowskiego por.: Latopis kijowski 1159-1198, oprac. E. Goranin, Wrocław 1988, s. 15-16, oraz Полное собраніе русскихъ льтописей изданное по повельнію Императорскою Археографическою Коммиссіею, t. 2: Ипатьевская Лътопись, С.-Петербургъ 1908, oraz reprint z 1998 r. z nowym wstępem, Москва 1998.

${ }^{25}$ F. Sielicki, Polsko-ruskie stosunki kulturalne do końca XV wieku, Wrocław 1997, ,Slavica Wratislaviensia", t. 93, s. 133.

${ }^{26}$ F. Sielicki, op. cit., s. 34, 106.

${ }^{27}$ Полное собраніе русскихъ лютописей, s. 318, 384, 385, 387, 662, 686, 687. 
Межькоуемь to znaczy we frazie *Межькомь оуемь. Mamy tu bez mała cały paradygmat odmiany twardotematowego imienia w rodzaju męskim w trzeciej deklinacji ruskiej redakcji cerkiewnej słowiańszczyzny. Należy jednak podkreślić, że tak konserwatywnie zapisane formy, tj. z konsekwentnie zaznaczanymi jerami, występują tylko w Kodeksie hipackim; dwa pozostałe zwody - chlebnikowski oraz pogodinski - wykorzystane do wydania Latopisu kijowskiego - są znacznie późniejsze (odpowiednio XVI i XVII w.) i w nich takiego zapisu już nie ma - wydanie faksymiliów wskazuje, że w tych rękopisach imię książęce jest zwykle podawane jako Мека $\mathrm{z}$ nadpisanym $\varkappa^{28}$.

W XII w., a więc w czasach panowania i senioratu Mieszka Starego,jerów w dialektach polskich już nie było; analiza zjawisk językowych (konkretnie brak „przegłosu lechickiego” w leksemach z samogłoską [e] pochodzącą z wokalizacji jerów) wskazuje, że zanikły one w XI w. ${ }^{29} \mathrm{~W}$ dialektach ruskich wokalizacja jerów nastąpiła dopiero na koniec wieku XII ${ }^{30}$. Jeżeliby zatem rusko-cerkiewna forma piastowskiego imienia dynastycznego miała zostać zapożyczona z dawnej polszczyzny, musiałoby mieć to miejsce w początkach XI w. Automatycznie niejako przychodzą na myśl:

a) czasy wyprawy Bolesława Chrobrego na Kijów i bicie monet pisanych cyrylicą, będących prawdopodobnie jednym z jej efektów; występuje na nich imię piastowskiego władcy z zapisanym na końcu jerem twardym БОЛЕСЛАВЪ ${ }^{31}$,

b) czasy Mieszka II, Gertrudy i Kazimierza Odnowiciela, tj. czasy bardzo bliskich rodzinnych relacji między Piastowicami a Rurykowiczami.

${ }^{28}$ The Old Rus' Kievan and Galician-Volhynian Chronicles: The Ostroz'kyj (Xlebnikov) and Četvertyns'kyj (Pogodin) Codices, wyd. O. Pritsak, Cambridge, Mass. 1990, s. 296 - kodeks chlebnikowski oraz s. 647 - kodeks pogodinski.

${ }^{29}$ K. Długosz-Kurczabowa, S. Dubisz, Gramatyka historyczna języka polskiego, Warszawa 2006, s. 104.

${ }^{30}$ Z. Stieber, Zarys gramatyki porównawczej języków słowiańskich, Warszawa 1979, s. 50.

${ }^{31}$ R. Kiersnowski, O tzw. ,ruskich” monetach Bolesława Chrobrego, w: Studia historica. W 35-lecie pracy naukowej Henryka Łowmiańskiego, red. A. Gieysztor, Warszawa 1958, s. 93-103, zwłaszcza s. 93-94: „Wśród znanych dziś produktów wczesnośredniowiecznego mennictwa polskiego denary «ruskie» tworzą grupę wprawdzie niezbyt znaczną, ale nie należą do unikatów. Literatura notuje ok. 10 ich egzemplarzy [- - ]. Stanowią więc one ok. 7\% w stosunku do łącznej liczby ok. 140 zarejestrowanych dziś monet Bolesława Chrobrego. Egzemplarze te reprezentują 5 różnych odmian stempla [--]. Wyobrażenia umieszczone na stemplach denarów «ruskich» przedstawiają w awersie popiersie władcy en face [- - ]. Po obu stronach tej postaci rozmieszczony jest w dwóch wierszach cyrylicki napis Болеславъ. Stronę odwrotną wypełnia krzyż tzw. patriarchalny, o rozwiniętych ramionach, pomiędzy którymi biegnie w pobliżu krawędzi ten sam napis Болеславъ". 
Dwunastowieczna ruska pisownia byłaby zatem pisownią historyczną, nieoddającą już współczesnej jej polskiej fonetyki.

Nie ulega wątpliwości, że w interesujących nas tutaj czasach cyrylica stanowiła tę formę alfabetu, która pozwoliłaby na zapis większości cech fonetycznych polszczyzny XI i XII w. Nie da się tego powiedzieć o pozostałych alfabetach używanych w ówczesnej Europie: greckim, łacińskim, hebrajskim czy arabskim (pomijam ormiański i gruziński). Rusko-cerkiewna, czyli cyrylicka forma niesie więc ze sobą trzy niezwykle ważne informacje dla interpretacji poświadczeń imienia zapisanych innymi alfabetami, tj. łacińskim, arabskim i hebrajskim:

- imię jest trzysylabowe, tak jak w najstarszych łacińskich poświadczeniach, tj. w Res gestae Saxonicae sive annalium libri tres Widukinda z Nowej Korbei (ca 925 - po 973), gdzie występuje w wersji „Misaca”32, oraz w Kronice (Thietmari Merseburgiensis episcopi chronicon) Thietmara (975-1018), gdzie z kolei odczytujemy wersję imienia „Miseco”33;

- wygłosowa sylaba to [ka] - świadczy o tym nie tylko pisownia, ale także paradygmat deklinacyjny (istnieją jednak imiona, w których możliwy jest zarówno przyrostek -ko, jak i -ka, np. Fałka <=> Fałko ${ }^{34}$ );

- środkowa spółgłoska to [ž] (IPA [3]), z pewnością palatalne.

Stanisław Rospond ${ }^{35}$ oraz J. Hertel ${ }^{36}$ przeprowadzili najdokładniejszą, jak do tej pory, analizę wszystkich poświadczeń imienia pierwszego historycznego władcy Polski ${ }^{37}$; wnioski, do których dochodzą, bynajmniej nie są zbieżne, aczkolwiek obaj w zasadzie odrzucają świadectwo cyrylickie z nie całkiem oczywistych powodów: Rospond pisze o bliżej niesprecyzowanych względach filologicznych i lingwistycznych ${ }^{38}$; Hertel zaś o tym, że „łaciński alfabet dysponuje także środkami umożliwiającymi odróżnienie $s z$ od ż"39, co stoi w wyraźnej sprzeczności z wcześniejszymi badaniami Rosponda ${ }^{40}$. Tymczasem przyjęcie cyrylickiego świadectwa pozwoliłoby nam na:

${ }^{32}$ Die Sachsengeschichte des Widukind von Korvei, wyd. H. E. Lohmann, P. Hirsch, Hannover 1935, MGH SrG, lib. III, c. 66, s. 141.

${ }^{33}$ Die Chronik des Bischofs Thietmar von Merseburg und ihre Korveier Überarbeitung, wyd. R. Holtzman, Berlin 1935, MGH SrG n.s., t. 9, lib. IV, c. 11, s. 145 i passim.

${ }^{34}$ W. Taszycki, Najdawniejsze polskie imiona osobowe, w: idem, Rozprawy i studia polonistyczne, t. 1: Onomastyka, s. 32-148, Wrocław-Kraków 1958 (pierwodruk: „Rozprawy Wydziału Filologicznego PAU”, t. 62, nr 3, 1925), s. 80.

35 S. Rospond, Uwagi polemiczne o Mieszku, Masławie i Dąbrówce, „Onomastica” 1, 1955, s. 169-185.

${ }^{36}$ J. Hertel, op. cit., s. 73-85.

${ }^{37}$ Por. także: J. Strzelczyk, op. cit., s. 59-65, G. Labuda, op. cit., loc. cit., oraz P. Urbańczyk, op. cit., s. 167-190.

38 S. Rospond, op. cit., s. 173.

${ }^{39}$ J. Hertel, op. cit., s. 82.

${ }^{40}$ S. Rospond, op. cit., loc. cit. 
a) zaproponowanie etymologii imienia, popartej pośrednio quasi-legendarną relacją Galla Anonima: „Mieszko” (a w zasadzie „Mieżko”"41) znaczyłoby pierwotnie „ślepiec” czy „niedowidzący”;

b) potwierdzenie najwcześniejszej, trzysylabowej wersji imienia zapisanej w cytowanych wyżej „niemieckich” relacjach Widukinda z Nowej Korbei czy Thietmara z Merseburga, ale także w „polskim” „Dagome iudex”, gdzie Mieszko Mieszkowic występuje jako „Misica”;

c) pokazanie historycznego rozwoju imienia z trójsylabowej do dwusylabowej (po zaniku jerów) postaci; zanik jerów doprowadziłby także do powstania grupy spółgłoskowej [*żk], która w polszczyźnie - podobnie jak w pozostałych (poza ukraińskim) językach słowiańskich ulega regresywnej neutralizacji dźwięczności obstruentów, „tzn. spółgłoski bezdźwięczne udźwięczniają się w pozycji przed spółgłoską (właściwą) dźwięczną, zaś spółgłoski (właściwe) dźwięczne ulegają ubezdźwięcznieniu”" ${ }^{2}$. Dawny „Mieżka” (viz. „Mieżko”) przyjąłby później po polsku ortograficzną (ale uwarunkowaną fonetyką) postać „Mieszka”/,Mieszko”, co doprowadziło do całkowitego zapomnienia źródłosłowu. Latynizacja imienia z kolei i przypisanie go do łacińskich paradygmatów deklinacyjnych dałyby postać Mesco,-onis. Można tu porównać historię imienia „Zbigniew” - uwarunkowana łacińską ortografią („Sbigneus”) współczesna postać imienia nie pozwala na dostrzeżenie czasownikowego źródłosłowu „zbyć"43; co ciekawe, nie przeszkadza to jednak nikomu w tworzeniu zdrobnień typu „Zbyszek" z etymologicznym [y].

Historyczny rozwój fonetyki w odniesieniu do imienia pierwszego historycznego władcy Polski wyjaśniłby również świadectwo Mistrza Wincentego zwanego Kadłubkiem, dla którego polszczyzna była przecież językiem ojczystym. W Kronice Polskiej czytamy: „Dictus vero est Meska, id est turbatio, quia caeco nato parentes turbati sunt" ${ }^{4}$.

${ }^{41}$ Propozycja Jana Otrębskiego (Imiona pierwszej chrześcijańskiej pary książęcej w Polsce, ,Slavia Occidentalis”, t. 18, 1939-1947, s. 85-125), by tak rekonstruowane pierwotne brzmienie imienia oprzeć na zdrobnieniu imienia Kazimierz, napotyka zdaniem Andrzeja Siuduta poważne problemy w „uzasadnieniu rozwoju historycznego” (A. Siudut, Trzy zagadkowe imiona , Onomastica” 1, 1955, s. 166-168).

${ }^{42}$ H. Dalewska-Greń, Języki słowiańskie, Warszawa 2002, s. 108.

${ }^{43}$ O. Balzer, Genealogia Piastów, Kraków 1895, s. 114.

${ }^{44}$ Tekst łaciński za: MPH, t. 2, s. 276. Tekst w przekładzie Brygidy Kürbis „Nazwany zaś został 'Mieszka', to jest 'zmieszanie', ponieważ rodzice skłopotali się, gdy urodził się ślepy”. (Mistrz Wincenty Kadłubek, Kronika polska, przeł. i oprac. B. Kürbis, Wrocław 2003. Tekst łaciński w wersji MPH n.s., t. 11, s. 38: „Dictus uero est Mesca id est turbatio, quia ceco nascente parentes turbati sunt". 
Współczesny Mieszkowi III Staremu Kadłubek usiłował zrozumieć piastowskie imię w ówczesnym jego brzmieniu, gdy już nikt nie pamiętał o pierwotnych jerach - współczesna polszczyzna oddaje to słowo jako 'zmieszanie'. Brak odpowiedniości tak rozumianego imienia względem znaczenia i funkcji sprawowanej przez pierwszego historycznego władcę Polski skłonił zapewne Jana Długosza do wymyślenia nigdy i nigdzie wcześniej niepoświadczonego imienia „Myeczslaw” ('habiturus gloriam' - „mający mieć sławę”), od którego ‘Mieszko' miałoby być zdrobnieniem („diminucio vocitationis”) ${ }^{45}$.

Proponowane tutaj odczytanie passusu Galla Anonima jako odniesienia do Księgi Izajasza i w konsekwencji przyjęcie, że już w najstarszej „polskiej” kronice imię pierwszego chrześcijańskiego władcy pozostaje w związku z jego dziecięcą ślepotą, oraz uznanie ruskiej wersji imienia za najważniejszą w odniesieniu do etymologii pozwala wyjaśnić wiele wątpliwości. Pozostawia jednak nierozwiązaną kwestię wielkiej popularności tego imienia w dynastii piastowskiej. Jeżeli pierwszy historyczny władca urodził się jako ślepiec i dano mu imię od jego fizycznej przypadłości, to dlaczego posłużyło ono także dwunastu innym Piastowicom, o których ślepocie nic nam nie wiadomo? ${ }^{46}$

Można, moim zdaniem, zaproponować następujące wyjaśnienie: Po śmierci Dobrawy (977) żeni się Mieszko z Odą, córką margrabiego Dytryka (979 lub 980). Oda rodzi Mieszkowi trzech synów: Mieszka, Świętopełka i Lamberta; spośród nich tylko Mieszko i Lambert są wymienieni w „Dagome iudex” - darowiźnie „państwa gnieźnieńskiego”(„civitas Schinesghe”) na rzecz papiestwa, co prawdopodobnie oznacza, że Świętopełk w momencie spisania tego dokumentu już nie żył. Gerard Labuda ${ }^{47}$ opowiada się za powstaniem tego aktu na czasy tuż przed śmiercią Mieszka I, tj. na lata 991-99248. Bolesław Chrobry, pierworodny syn Mieszka I z małżeństwa z Dobrawą, żeni się po raz trzeci w 987 r.; jego trzecią żoną jest Emnilda, córka księcia Dobromira.W roku 990 Emnilda rodzi pierwszego syna; otrzymuje on podwójne imię Mieszko Lambert, czyli dokładnie te, które noszą żyjący synowie Mieszka I z jego małżeństwa z Odą. Można z tego wysnuć wniosek, iż imię „Mieszko" miało oznaczać prawo do dziedzictwa, a fakt, że Bolesław nadał swojemu synowi-spadkobiercy imiona obu konkurentów do Mieszkowego dziedzictwa i po śmierci ojca wygnał ich (razem z macochą) z piastowskiego księstwa, taką argumentację bardzo wspiera. Podob-

${ }^{45}$ Ioanni Dlugossii Annales seu cronicae incliti regni Poloniae, t. 1-11, Varsaviae 19642005, lib. I, s. 170-171.

${ }^{46}$ O. Balzer, op. cit., s. 3-14 oraz strony z tablicami genealogicznymi.

${ }^{47}$ G. Labuda, op. cit., s. 177.

${ }^{48}$ Jerzy Strzelczyk próbuje nawet podać datę dzienną: 5 kwietnia 991 r.(op. cit., s. 176). 
nie zresztą jak i fakt emisji Bolesławowego denara z napisem GNEZDVN CIVITAS, o ile zgodzimy się z interpretacją Andrzeja Schmidta, że został on wybity „zaraz po objęciu przez Bolesława Chrobrego rządów nad "państwem gnieźnieńskim» i stanowił wyraz triumfu ze zwycięstwa nad Odą i opozycją" ${ }^{49}$. Trudno oczywiście założyć, że już pierwsi Piastowie znali na tyle historię Imperium Romanum, by się wzorować na Juliuszu Cezarze i Oktawianie Auguście (obaj nazywali się Gaius Iulius Caesar), ale nie sposób wykluczyć (choć niepodobna także dowieść) podobnego sposobu myślenia, zwłaszcza że ma on swoją paralelę także w imieniu „Otto(n)”, przenoszonym z ojca na syna w pierwszym współczesnym Piastom stricte historycznym cesarskim rodzie Ludolfingów.

W fałszywie przypisanym Herodotowi fantastycznym żywocie Homera (Vita Homeri), pochodzącym być może nawet z II w. n.e. ${ }^{50}$, możemy znaleźć stwierdzenie, że mieszkańcy Kyme używają słowa homeros na określenie ślepca ${ }^{51}$. Trudno sobie wyobrazić dzieje kultury greckiej i szerzej europejskiej bez Homera-Ślepca, którego imię stało się symbolem poezji epickiej; trudno też sobie wyobrazić dzieje i kulturę polską bez Mieszka, pierwszego historycznego i chrześcijańskiego władcy państwa polskiego. Jeżeli zatem imię „Mieszko” oznacza pierwotnie 'ślepca', to znalazł się on w dobrym towarzystwie.

\section{The Name of the First Historical Ruler of Poland}

Despite numerous studies the etymology of the name: "Mieszko" still remains unclear. An analysis of the manuscript of Gesta by Gallus Anonymous describing, i.a. Mieszko I, makes it possible to discern a crypto-quotation from the Latin text of The Book of Isaiah $(65,15)$. The chronicler stressed the duke's baptism and childhood blindness/impaired vision. This is an argument supporting an explanation of the meaning of the name of the ruler of the Polans, based on an Old Slavonic verbal root: "to wink, to blink, to tremble".

The oldest Latin versions of the ruler's name, originating from the tenth and eleventh centuries, are composed of three syllables, as confirmed also by the Cyrillic Kiev Codex (end of the twelfth century), part of the Hypatian Chronicle, which consistently recorded reduced vowels, so-called yers, in the name of Mieszko the Old: mežıka (in all likelihood, the oldest version of the name). The disappearance of the yers in Polish and the name's Latinization would subsequently produce the form: Mesco, from which "Mieszko" could be directly derived. The historical progress of

${ }^{49}$ J. Strzelczyk, op. cit., s. 187. Więcej na temat znaczenia Gniezna w tych czasach: A. Buko, Archeologia Polski wczesnośredniowiecznej. Odkrycia - hipotezy - interpretacje, Warszawa 2011, s. 228-229.

${ }^{50}$ J. Łanowski, Wstęp, w: Homer, Iliada, Wrocław 1972, s. III-LXXXIX, tu XV.

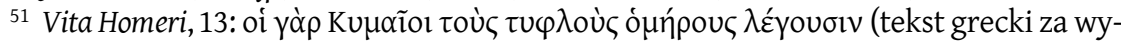
daniem Thesaurus Linguae Graecae On-line, 〈http://www.tlg.uci.edu〉, dostęp: 31 III 2012). 
the Polish language should also explain an attempt at translating the name of the ruler into Latin, made by Master Wincenty (Kadłubek).

The titular name, which originally was a moniker, could have bestowed a right to the throne. It also became a dynastic name used by the Piasts - an excellent parallel can be "Otto(n)" in the Ludolfing imperial dynasty.

Translated by Aleksandra Rodzińska-Chojnowska 